\title{
COMPARATIVE SUSCEPTIBILITY OF SOME COMMERCIAL POTATO CULTIVARS TO FUSARIUM SAMBUCINUM AND F. SOLANI ISOLATES CAUSING TUBER DRY ROT
}

\author{
AYDIN, M. H. $^{{ }^{*}}-$ İNAL, B. ${ }^{2}$ \\ ${ }^{I}$ Department of Plant Protection, Faculty of Agriculture, Siirt University, Siirt, Turkey \\ ${ }^{2}$ Department of Agricultural Biotechnology, Faculty of Agriculture, Siirt University, Siirt, \\ Turkey \\ *Corresponding author \\ e-mail: hadiaydin@siirt.edu.tr; phone: +90-536-599-9794 \\ (Received $31^{\text {st }}$ May 2018; accepted $17^{\text {th }}$ Jul 2018)
}

\begin{abstract}
Fusarium dry rot is one of the most important diseases of potato (Solanum tuberosum L.), affecting the tubers in storage and the seed pieces after planting. Fusarium sambucinum and F. solani are common pathogens causing dry rot of stored tubers in temperate areas. In this study, infection of $F$. sambucinum and $F$. solani on tissue discs prepared from tubers of potato varieties that are susceptible or moderately resistant to this disease was studied. Tubers were wounded, inoculated, incubated at $15-20{ }^{\circ} \mathrm{C}$ for 5 weeks and the size of the rot was assessed. All isolates were found pathogenic to potato tubers and differed in pathogenicity. Obtained results revealed that Fusarium isolates showed variable aggressivity upon the 17 tested potato cultivars. Furthermore, no cultivars were found to be completely resistant to the whole Fusarium isolates, and only one cultivar showed a lesser susceptibility to pathogen. This cultivar was $B r^{\circledR}{ }^{\circledR}$. Moreover, $F$. sambucinum isolates were detected as more aggressive pathogens than $F$. solani in all cultivars. Additionally, one out of three isolates of $F$. sambucinum was more aggressive than the others. All isolates used in this study were identified both based on colony and conodial morphology and also confirmed by molecular methods.
\end{abstract}

Keywords: Solanum tuberosum, Fusarium spp., dry rot, assesment, aggressivity, molecular detection

\section{Introduction}

Potato (Solanum tuberosum L.) is among the top five crops growing world wide following cereals wheat, rice, corn and barley due to its high carbohydrate content and adaptability. It is an important source of calorie, protein and fat for humans, industrial raw material for starch and alcohol production and also feed for animals. Global annual production of potato in 2016 was about 376.827.000 tonnes (FAOSTAT, 2017). The annual yield loss of potato crop caused by insects, weed and diseases in the developing countries such as Turkey is determined to be $32.4 \%$. Diseases alone are responsible for $21.8 \%$ of yield reduction (Eken et al., 2000). Losses associated with dry rot have been estimated to range from $6 \%$ to $25 \%$, and occasionally losses as great as $60 \%$ have been reported during long-term storage (Estrada et al., 2010; Secor and Salas, 2001). Dry rot is caused by a number of Fusarium species affecting sprouting and emergence at the beginning of the season, which results in yield loss and damage to the quality of daughter tubers, especially during storage (Corsini and Pavek., 1986; Hooker, 1981; AlMughrabi, 2010; Borca and Carmen., 2013). Furthermore, there may be potential reductions due to other reasons, such as bacterial soft rot. Fusarium species are known to cause dry rot, particularly $F$. sambucinum and $F$. solani are the most common pathogens. To establish strategies for the control of this disease, the primary steps would be to make a correct diagnosis and identify the pathogen on potato. In recent 
years, the increasing use of molecular methods in fungal diagnostics enabled a reliable and rapid identification. The most important method of control against this disease is to grow resistant varieties. But potato cultivars vary in their degree of resistance to $F$. sambucinum and other Fusarium species

The objectives of this study were: (1) to identify the $F$. solani and $F$. sambucinum isolates obtained from potato dry rot, (2) to identify the virulence of these isolates by comparison with each other, and finally (3) to test some commercial potato varieties for their tolerance to $F$. sambicunum and $F$. solani isolates causing potato dry rot in Turkey.

\section{Review of literature}

F. sambucinum Fuckel (F. sulphureum Schlecht)- teleomorph Giberella pulicaris (Fr.) Sacc.- is the most common pathogen worldwide causing dry rot of stored tubers, but other Fusarium species are also known to cause dry rot, particularly $F$. solani (Mart.) Sacc., F. avenaceum (Fr.) Sacc. F. oxysporum Schltdl., F. culmorum (W.G. Sm.) Sacc., and F. graminearum Schwabe (Boyd, 1972; Nelson et al., 1981; Hanson et al., 1996; Eken et al., 2000; Borca and Carmen, 2013; Stefańczyk et al., 2016). Among these fungi, $F$. sambucinum is the most aggressive species both in the world and in Turkey (Boyd, 1972; Hide et al.1992; Hanson et al., 1996; Secor and Salas, 2001; Eken et al., 2000; Du et al., 2012; Aydin et al., 2016). However, some researchers have suggested that other important Fusarium species may cause the dry rot. For example, $F$. oxysporum was reported to be the primary agent responsible for potato dry rot among 11 species in Michigan, USA (Gachango et al., 2012). According to Choiseul et al. (2007), F avenaceum was found to dominate pathogens in Fusarium population that was examined on potato between 1997 and 2000 in Scotland. Three significant Fusarium species, namely $F$. coeruleum, $F$. sambucinum and $F$. solani, have been reported to principally cause the potato dry rot under temperate conditions (Corsini and Pavek, 1986; Daami-Remadi et al., 2006; Daami-Remadi et al., 2012). Isolated outbreaks of disease have been caused by highly pathogenic species and $F$. sambucinum in Scotland was associated with post-storage rotting (Cullen et al., 2005). In addition to destroying tuber tissues, $F$. sambucinum can produce toxins that have been implicated in mycotoxicoses of the human beings and animals (Richardson and Hamilton, 1987; Senter et al., 1991; Schisler et al., 1997; Sveeney and Dobson, 1999).

Potato cultivars vary in their degree of resistance to $F$. sambucinum and other Fusarium species (Jellis, 1975; Hooker, 1981; Jellis and Starling, 1983; Wastie et al., 1989). All of the commonly grown potato cultivars in North America are susceptible to the pathogen, but some are less susceptible than the others (Tivoli et al., 1986).

Sources of resistance to pathogens in potato tubers are given in some literature. In resistant tissues lesion enlargement is confined to the infection spot, which might be due to the suberin deposition in the host cells. It involves formation of lignin, suberin, waxes or wound gums in the immediate cells next to the wounded surface. However, further studies imply that formation of lignin and suberin components of periderm may actively be involved in the defense of pathogens. Independent genetic factors are involved in controlling resistance against major Fusarium species on potato (Vance et al., 1980; Wastie et al., 1989; Huaman et al., 1989; Valluru et al., 2016). According to DaamiDaami-Remadi et al. (2006) some Fusarium species indicated unstable aggressivity upon some of the tested potato cultivars. $F$. graminearum was the most aggressive pathogen on majority of the cultivars, whereas $F$. sambucinum, $F$. solani and $F$. 
oxysporum showed a comparable aggressivity on some cultivars used. All inoculated tubers showed dry rot symptoms with different degrees, which revealed that cultivars' resistance differed against Fusarium species (Daami-Remadi et al., 2006). $F$. sambucinum was found to be the most aggressive species in a study conducted by Du et al., 2012 in Chine and according to that study, 56\% of the isolates belonged to these species and Sixty-seven clones were identified as susceptible to $F$. sambucinum. Another survey was carried out in Central Europe by Latus-Ziętkiewicz et al. (1987). According to this study, $F$. sambucinum was the main pathogen causing dry rot in Poland between 1985 and 1986.

To establish strategies for the control of this disease, the primary steps would be to make a correct diagnosis and identify the pathogen on potato. (Borca and Carmen, 2013; Aydin et al., 2016). It is primarily based on cultural and morphological characters such as the microscopic morphology including shape and size of the macroconidia, the presence or the absence of the microconidia and of the chlamydospores (Gerlach and Nirenberg, 1982; Burgess et al., 1994; Nelson et al., 1983). But in recent years, the increasing use of molecular methods in fungal diagnostics enabled a reliable and rapid identification. These methods are based on the PCR amplification of species-specific DNA fragments using fluorescent oligonucleotide primers, which were designed based on sequence divergence within the internal transcribed spacer region of nuclear ribosomal DNA sequences. This method provided an accurate, reliable and quick diagnosis of Fusarium species including F. sambucinum (Mishra et al., 2003; Visentin et al., 2009; Powel et al., 1996; Abd-Elsalam et al., 2003; Oechsler et al., 2009; Wang et al., 2011).

\section{Material and methods}

\section{Potato cultivars}

Potato cultivars tested in this study are listed in Table 1 . They are provided by the various agricultural companies and they are stored in darkness at $4{ }^{\circ} \mathrm{C}$ until the experiments were carried out.

\section{Microorganisms and identification}

The strains of $F$. sambucinum (Fs2, Fs3 and Fs4) and F. solani (Fs1) are used in this study were taken infected potatoes from Afyon potato production area in the autumn season. They were isolated from the infected potato tubers of cv. Lady Rosetta with typical symptoms of dry rot and it was previously reported to be virulent on potato tubers (Aydin et al., 2016). The strains were maintained on potato dextrose agar (PDA, $38 \mathrm{~g}$ and sterile water, made up to 1 litre). Before starting work, pure tubers were infected with isolates and re-isolated. Thus, the isolates were maintained in virulence. The single spore technique was used to obtain a pure culture of Fusarium isolates. The color of colonies of strains obtained ranged from white to moderate pink. Isolates were stored in the tube at $+4{ }^{\circ} \mathrm{C}$ until it starts to work. Synthetic Nutrient Agar (SNA, Difco), Potato Dextrose Agar (PDA, Merck) and 1/10 diluted PDA media were used for morphological and microscopic identification. All Fusarium isolates were initially identified according to their morphological and microscopic characters as described by Booth (1977), Gerlach and Nirenberg (1982), Nelson et al. (1983), Hasenekoğlu (1991), Burgess et al. (1994), Leslie and Summmerell (2006), Borca and Carmen (2013). And 
then, identification of the isolates was further confirmed by molecular approach. Processes related to pathogen isolation and identification are given in Figure 1.

\section{Molecular identification of Fusarium isolates}

DNA isolation, PCR condition and phylogenetic analysis

Fungal Genomic DNA was extracted from mycelium by using the methodology as proposed by Doyle (1987). DNA quality was checked on $1 \%$ agarose gel, and then quantification was measured by using the Nanodrop (Thermo Scientific). To achieve the amplification of ITS4-ITS5 region of nuclear genome, PCR was performed in $25 \mu 1$ volume. This volume occurred from $80 \mathrm{ng}$ of total genomic DNA, 10 pmol both primers, $200 \mu \mathrm{M}$ dNTP, $2 \mathrm{mM} \mathrm{MgCI} 2$, $1 \mathrm{X}$ Taq buffer, $1 \mathrm{U}$ of Taq Polymerase $(5 \mathrm{U} / \mu \mathrm{L}$, catalog number: EP0402) and $\mathrm{ddH}_{2} \mathrm{O}$ for complete the last volume. PCR products were separated by gel electrophoresis on $1.5 \%$ agarose gels, containing ethidium bromide, and photographed under UV light in a gel doc system. PCR products of ITS4-ITS5 region were sequenced by Iontek Company, Istanbul, Turkey.

\section{Alignment and phylogenetic analysis}

The obtained sequences were Blasted (basic local alignment search tool) by using the NCBI (National Center for Biotechnology Information) database and percent homology scores were assessed to identify Fusarium spp. Phylogenetic trees were made with MEGA version 7 (Tamura et al., 2007). Using a neighbor-joining algorithm, bootstrap analyses for 1000 replicates were performed.

Table 1. Characteristics of potato cultivars tested for their tolerance to F. sambucinum and F. solani isolates causing potato dry rot in Turkey

\begin{tabular}{c|c|c|c|c|c}
\hline Cultivars* & Tuber shape & Skin color & Flesh color & $\begin{array}{c}\text { Dry matter } \\
(\boldsymbol{\%})\end{array}$ & Usage \\
\hline Marabel & Oblong & Yellow & White & 19.2 & Cooking \\
Madeleine & Round-oval & Yellow & Yellow & 18.2 & Cooking \\
Hermes & Round-oval & Yellow & Ochre & 28.4 & Crisps \\
Opal & Round oval & Yellow & Light yellow & Medium & Crisps \\
Brooke & Round oval & Yellow & Medium yellow & ---- & Crisps \\
Lady Claire & Round & Thin yellow & Light yellow & 23.8 & Crisps \\
Musica & Long-oval & Light yellow & Yellow & 19.7 & Cooking \\
Orchestra & Round oval & Light yellow & Light yellow & 17.7 & Cooking \\
Melody & Oval & Yellow & Medium yellow & 20.5 & Cooking \\
Vr. 808 & Round & Yellow & Light yellow & 25.1 & Crisps \\
Lady Rosetta & Round & Red & Light yellow & 24.9 & Crisps \\
Desiree & Smooth & Red & Creamy white & 21.7 & Cooking \\
Surya & Oblong & White & Pale yellow & ---- & Crips \\
Alonso & Round & Yellow & Light yellow & ---- & ----- \\
Alegria & Oval & Bright-yellow & Light yellow & 20.5 & Crips \\
Borwina & Round oval & Bright yellow & Yellow & 20.5 & Cooking \\
Soraya & Round & Yellow & Light yellow & ---- & Cooking
\end{tabular}

*These potato varieties are grown and registered in Turkey 

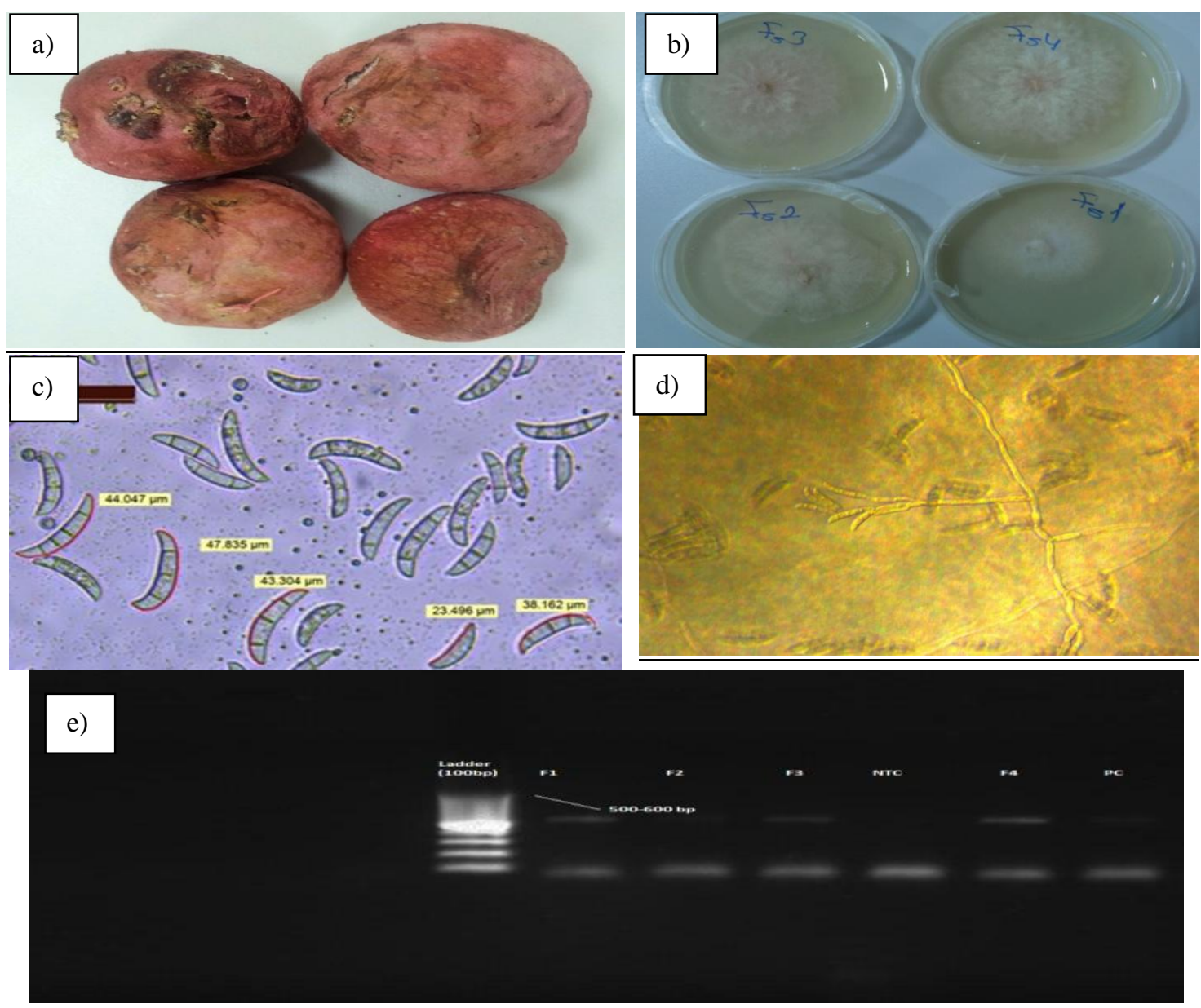

Figure 1. Isolation and identification of Fusarium isolates. (a) Infected potato tuber by dry rot. (b) Culture purification of Fs isolates. (c) Macrocondia of Fs (d) Microconidia production by Fs. (e) molecular identification of Fs by species specific primer (NTC: No template control, PC:

Positive control)

\section{Evaluation of dry rot susceptibility to $F$. sambucinum and F. solani}

A total of 17 potato cultivars (Table 1) were selected to test their resistance to $F$. sambucinum (Fs1, Fs2, Fs3) and F. solani (Fs1). Symptom-free tubers of dry rot and other diseases were selected for the experiments and weighed from 80 to $100 \mathrm{~g}$. They were washed in running tap water, dipped in sodium hypochlorite $(5 \%)$ for $5 \mathrm{~min}$, rinsed twice with double distilled sterile water and air-dried for $24 \mathrm{~h}$. Potato tubers were wounded through inward with a drill $8 \mathrm{~mm}$ in diameter and $8 \mathrm{~mm}$ in depth. An $8 \mathrm{~mm}$ agar plug derived from the edge of a 7-day-old fungi colony on PDA was inserted into the drilled tuber hole. A control treatment consisting of a non-inoculated agar plug was inserted into the wounded tuber. The experiment was set up at room temperature of 15$20{ }^{\circ} \mathrm{C}$ in separate plastic boxes with sufficient relative humidity for five weeks. Every treatment was repeated for four times (one tuber $\mathrm{x}$ one wound). Treatments applied to seed pieces were: (1) not inoculated, (2) inoculated with $F$. sambucinum (Fs2); (3) inoculated with $F$. sambucinum (Fs3), (4) inoculated with $F$. sambucinum (Fs4) and (5) inoculated with $F$. solani (Fs1). After incubation period, tubers were cut through the inoculation site and the depth and width of the rot area were measured. Parameters of 
dry rot caused maximal width (w), depths (d) were noted, and tubers were calculated by applying the following formula devised by Lapwood et al. (1984):

$$
\text { Penetration (mm): }[\mathrm{w} / 2+(\mathrm{d}-6)] / 2
$$

Cultivar's susceptibility to F. sambucinum (Fs2, Fs3, Fs4) and F. solani (Fs1) was estimated according to this scale: Less or moderately susceptible: mean penetration $\leq 12$ $\mathrm{mm}$; Susceptible: $12 \mathrm{~mm}$ <mean penetration < $15 \mathrm{~mm}$; Highly susceptible: mean penetration $\geq 15 \mathrm{~mm}$. The data were analysed with SPSS (version 20, SPSS Inc. Chicago, Illinois) and means were separated with Duncan's multiple range test.

\section{Results and discussions}

\section{Molecular identification of F. sambucinum (Fs2, Fs3, Fs4) and F. solani (Fs1).}

Both F. sambucinum (Fs2, Fs3, Fs4) and F. solani (Fs1) were identified based on morphological structures as described by Booth (1977), Gerlach and Nirenberg (1982), Nelson et al. (1983), Hasenekoğlu (1991), Leslie and Summerrell (2006) and Borca and Carmen (2013) respectively. In addition for molecular analysis, sequences of ITS4 and ITS5 regions were compared by using the BLAST (basic local alignment search tool) in NCBI (National Center for Biotechnology Information) database in GenBank. Phylogenetic tree generated from the ITS sequence data was found to have a quite consistent resolution with our estimations. The resulting dendrogram (Fig. 2) showed that the analyzed ITS gene region represented the variability to differentiate from the isolate of Fusarium spp obtained from NCBI.

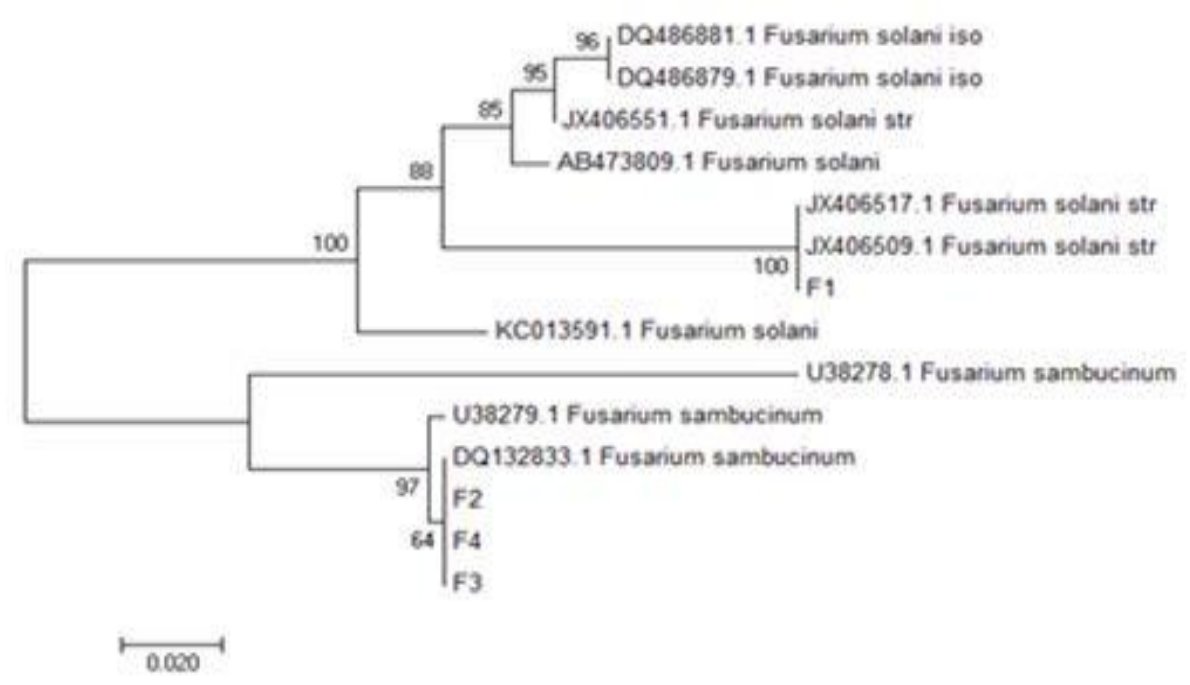

Figure 2. Phylogenetic tree based on neighbor-joining analysis of ITS sequences from NCBI and 4 isolated Fusarium spp. Bootstrap values are given when above 64\% (1,000 replicates)

Analyzed isolates formed two main branches. First main branch was consisted of investigated F1 and F. solani isolates obtained from NCBI. So it can be argued that F1 isolates showed a kinship with $F$. solani. The second main branch was built up by the investigated F2, F3 and F4 and F. sambucinum isolates obtained from NCBI. So it can 
be estimated that F2, F3 and F4 isolates showed a genetic kinship with $F$. sambucinum. We reach the conclusion that ITS region was found to be as a diagnostic tool to discriminate the investigated isolates in this study. Informative sequences of ITS region also help the close related Fusarium species such as $F$. verticillioides and $F$. proliferatum (Visentin et al., 2009). The least informative or low nucleotide sequence variation of the ITS region to clearly identify many complex species was also previously achieved (Oechsler et al., 2009; Wang et al., 2011). Determination of Fusarium spp. using thermal cycler amplification of ITS region of the rDNA using the right primer pairs are reliable, accurate and quick. Duggal et al. (1997) reported that the ITS region shows polymorphisms with in Fusarium spp. This is consistent with the previous study (White et al., 1990) and (O'Donnell, 1992) which under line the applicability of using the ITS region as a molecular marker to identify the Fusarium spp. It was also defined in these works that the rDNA region of $F$. sambucinum showed a highly conserved. Furthermore, small sequence divergence was found by using the ITS region that can determinate species from the same clan (Turner et al., 1998).

\section{Evaluation of dry rot susceptibility to $F$. sambucinum (Fs2, Fs3, Fs4) and F. solani (Fs1)}

Commercial variety susceptibility to Fusarium dry rot decay can affect the market value. Therefore, it is important to grow potatoes that are not susceptible to this disease. The mean dry rot scores are shown in Table 2, and analysis of variance is indicated in Table 3.

Table 2. Dry rot severity caused by $F$. solani $(F s 1)$ and $F$. sambucinum $(F s 2, F s 3, F s 4)$ in potato tubers in vivo test

\begin{tabular}{c|c|c|c|c|c}
\hline \multirow{2}{*}{ Varieties } & \multicolumn{5}{|c}{ The average severity diseases of isolates } \\
\cline { 2 - 6 } & Severity of Fs1 & Severity of Fs2 & Severity of Fs3 & Severity of Fs4 & Mean \\
\hline Marabel & 7.63 & 13.06 & 13.88 & 14.26 & $12.20 \mathrm{~h}^{*}$ \\
Madeleine & 7.25 & 13.44 & 18.00 & 11.94 & $12.65 \mathrm{gh}$ \\
Hermes & 7.94 & 18.75 & 14.38 & 13.81 & $13.71 \mathrm{fg}$ \\
Opal & 7.19 & 18.38 & 19.62 & 10.75 & $13.98 \mathrm{ef}$ \\
Broke & 7.75 & 13.81 & 11.25 & 10.13 & 10.73 \\
Claire & 9.31 & 10.38 & 18.19 & 14.25 & $13.03 \mathrm{fgh}$ \\
Musica & 8.25 & 24.50 & 19.38 & 16.56 & $17.17 \mathrm{c}$ \\
Orchestra & 10.44 & 17.81 & 13.38 & 13.06 & $13.67 \mathrm{fg}$ \\
Melody & 7.09 & 16.81 & 24.94 & 13.88 & $15.70 \mathrm{~d}$ \\
Vr.808 & 12.69 & 16.31 & 18.94 & 13.88 & $15.46 \mathrm{~d}$ \\
Rossetta & 12.81 & 12.13 & 16.88 & 8.00 & $14.95 \mathrm{de}$ \\
Desire & 9.56 & 14.56 & 15.13 & 14.31 & $13.39 \mathrm{fgh}$ \\
Surya & 8.81 & 21.13 & 28.06 & 6.25 & $21.06 \mathrm{a}$ \\
Alonso & 12.38 & 17.93 & 16.38 & 6.13 & $18.20 \mathrm{bc}$ \\
Alegra & 10.25 & 21.63 & 23.18 & 20.00 & $18.76 \mathrm{bc}$ \\
Borvira & 7.50 & 19.27 & 22.50 & 22.00 & $17.81 \mathrm{bc}$ \\
Soraya & 13.50 & 13.25 & 14.56 & 19.75 & $15.26 \mathrm{~d}$ \\
\hline
\end{tabular}

*Values in the same column followed by the same letter are not significantly different at $\mathrm{p}=0.05$. CV: $9.05 \%$ 
Table 3. Mean squares from the analysis of variance for dry rot inoculation tests

\begin{tabular}{c|c|c|c|c}
\hline $\begin{array}{c}\text { Variation source } \\
\text { (VS) }\end{array}$ & $\begin{array}{c}\text { Degree of freedom } \\
\text { (DF) }\end{array}$ & $\begin{array}{c}\text { Sum of squares } \\
\text { (SS) }\end{array}$ & $\begin{array}{c}\text { Mean of square } \\
\text { (MS) }\end{array}$ & F \\
\hline Replication & 3 & 17.088 & 5.696 & 2.09 \\
Variety & 16 & 1864.549 & 116.534 & $48.82^{* *}$ \\
Isolate & 3 & 3103.692 & 1034.564 & $380.21^{* *}$ \\
Variety*Isolate & 48 & 2213.389 & 46.112 & $16.94^{* *}$ \\
Error & 201 & 546.939 & 2.721 & \\
Total & 271 & 7828.586 & & \\
\hline
\end{tabular}

Coefficient of variation $(\mathrm{CV})=9.05 \%$

According to the variance analysis results, the disease reactions of the varieties against Fusarium isolates appear to be statistically significant at the level of $1 \%$. Susceptibility of Potato varieties to F. sambucinum (Fs2, Fs3, and Fs4) and F. solani (Fs1) isolates had different grades with average lesion sizes ranging from 10.73 to $21.06 \mathrm{~mm}$ (Table 2). Cultivars were evaluated in laboratory for 5 weeks at $15-20{ }^{\circ} \mathrm{C}$. Obtained results revealed that Broke had a less or moderately susceptible dry rot potential classification, whereas Musica, Melody, Vr.808, Surya, Alonso, Alegra, Borvira, Soraya had a high dry rot potential. The cultivars of Marabel, Madeleine, Hermes, Opal, Claire, Orchestra, Rossetta and Desire were also susceptible in terms of dry rot (Table 4, Fig. 3). Disease development of Fusarium dry rot can be increased depending on variety, harvest and handling conditions, tuber characteristics and storage temperatures. Previous studies have shown that the majority of varieties on the market were susceptible to this disease (Tivoli et al., 1986; Wastie et al., 1989; Kumar and Knowles, 2003; Burkhart et al., 2007; Lynch et al., 2003; Daami-Remadi et al., 2006; Du et al., 2012; Baturo-Cieśniewska et al., 2014; Stefańczyk et al., 2016). So, it is essential to incorporate good management practices in order to reduce Fusarium dry rot (Leach and Nielsen, 1975; Al-Mughrabi, 2010).

Table 4. Potato variety susceptibility to Fusarium dry rot

\begin{tabular}{c|c|c}
\hline Less or moderately susceptible & Susceptible & Highly susceptible \\
\hline Broke & Hermes & Musica \\
& Opal & Melody \\
& Claire & Vr.808 \\
& Orchestra & Surya \\
& Rosset & Alonso \\
& Desire & Alegra \\
& Marabel & Borvira \\
& Madeleine & Soraya \\
\hline
\end{tabular}

Different rates in terms of disease severity have occurred among the varieties against the same isolate. For example, F. solani (Fs1) caused disease severity on Soraya, Alonso, Vr.808, Rossetta, 13.50, 12.38, 12.68 and 12.81 respectively. On the other hand, some isolate again caused on Marabel, Madeleine, Hermes, Opal and Broke 7.63, 7.25, 7.94, 7. 19, $7.75 \mathrm{~mm}$, respectively (Table 2, Fig. 3). Similar results were obtained 
in some studies conducted in different countries (Hooker, 1981; Jellis and Starling, 1983; Tivoli et al., 1986; Wastie et al., 1989). According to Daami-Remadi et al. (2006), all inoculated tubers showed dry rot symptoms with different degrees, which reveal that cultivars' resistance differed against Fusarium species.

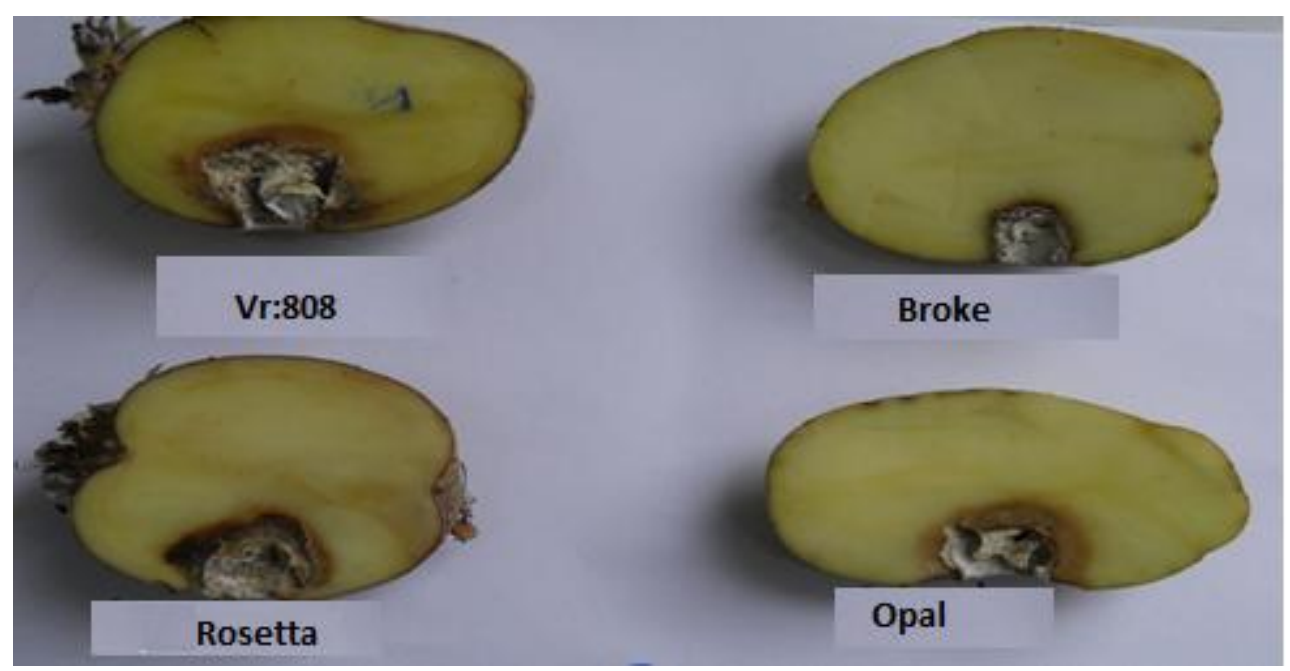

Figure 3. Dry rot symptom caused by $F$. solani $\left(F_{s} 1\right)$ isolates on tubers of the cultivar Vr.808, Rosetta (left) and Broke, Opal (right) after 5 weeks of incubation at $15-20{ }^{\circ} \mathrm{C}$

The isolates of whole $F$. sambucinum were more aggressive pathogens than those of the $F$. solani in all cultivars (Table 2). As given in Table 2, the mean diseases Severity of $F$. solani (Fs1) is 9.43, but the isolates of $F$. sambucinum (Fs2, Fs3, Fs4) were between 16.40-18.15 mm. For example, all isolates (Fs4, Fs3, Fs2, Fs1) caused disease severity on Surya cultivar at different rates, 26.25, 28.06, 21.13, 8.81 respectively (Table 2, Fig. 4).

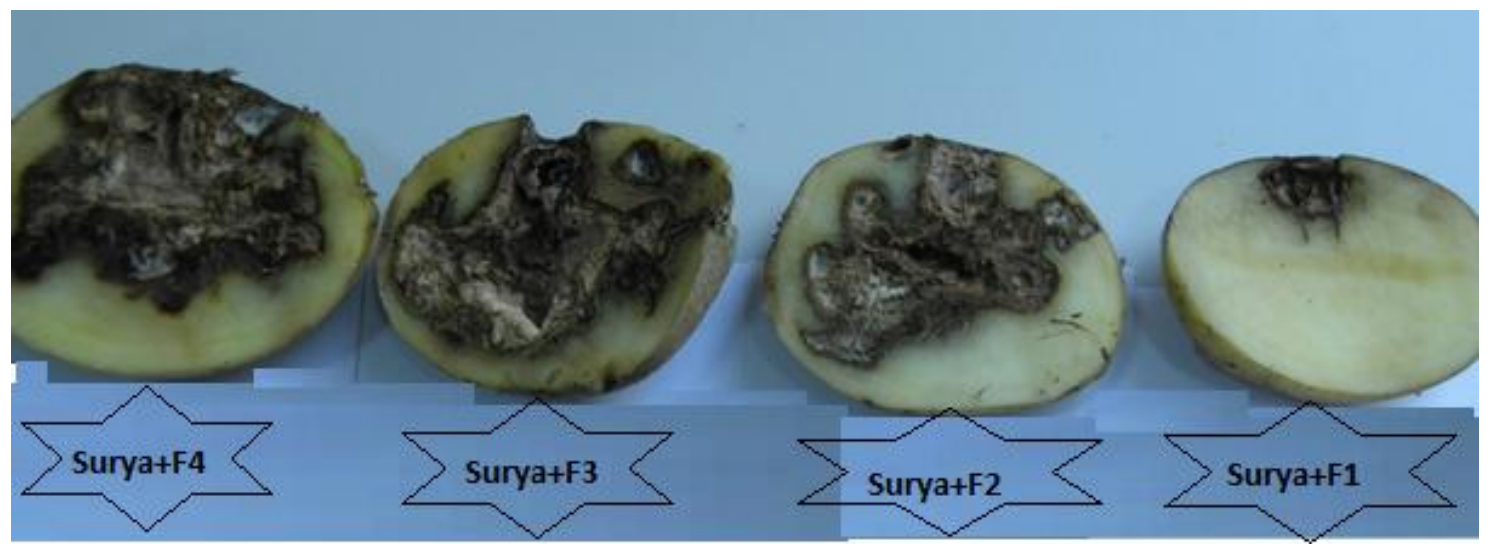

Figure 4. Dry rot symptoms caused by $F$. sambucinum $(F s 4, F s 3, F s 2)$ and $F$. solani $(F s 1)$ isolates on tubers of the cultivar Surya after 5 weeks of incubation at $15-20{ }^{\circ} \mathrm{C}$

According to this study, $F$. solani (Fs1) was a weaker pathogen. This result is not supported by some researchers. For example, Lenc et al. (2008) and Peters et al. (2008) have reported $F$. sambucinum and $F$. solani are more frequently associated with dry rot 
of tubers but $F$. solani is considered to be a more aggressive pathogen in most parts of Europe. However, this finding was supported by some other researchers who stated that F. sambucinum was more aggressive pathogen than the other Fusarium species which caused dry rot on potato (Corsini and Pavek, 1986; Wastie et al., 1988; Du et al., 2012; Aydin et al., 2016). In conclusion, this study also supports that several Fusarium spp. have been associated with potato dry rot. But depending on the geographic location and the season, the most frequent and devastating of these species is $F$. sambucinum. The isolates are used in this study obtained in Afyon potato production area in the autumn season. The severity of dry rot in this area was usually found to be high (Aydin et al., 2016).

As a result, susceptibility of varieties was found to be distinct to $F$. sambucinum isolates and $F$. solani. While Broke was less or moderately susceptible, other varieties such as Marabel and Madeleine were detected to be susceptible or highly susceptible to Fusarium dry rot according to the total disease severity of the four isolates on the varieties (Table 4.)

After Fusarium isolates grew on the PDA for seven days, they were classified into four different color groups based on mycelium shapes; white (Fs1), Light pink (Fs2), moderately pink (Fs3) and (Fs4). According to phylogenetic analysis also, Fs1 isolate was detected to be close to $F$. solani and the other three isolates are found to be close to F. sambucinum (Fig. 2). Regarding the color of colonies of isolates on PDA, Fs2 and Fs4 developed close to pink but Fs3 as moderately pink (Fig. 5).

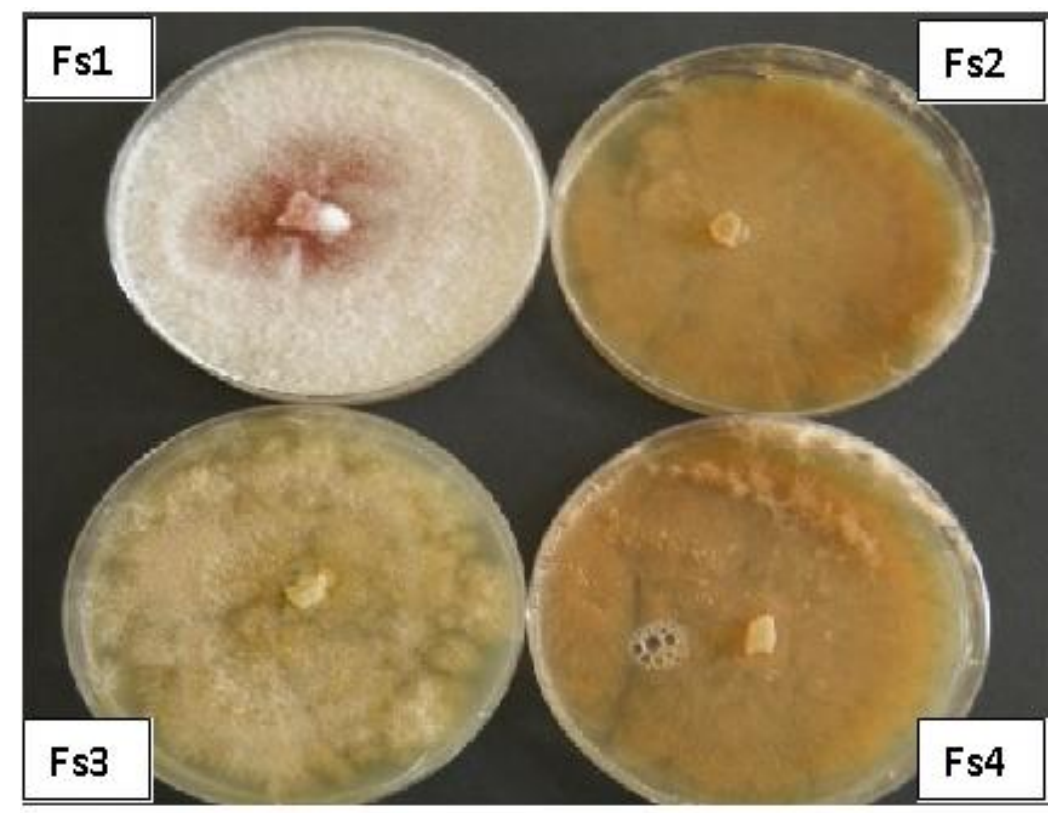

Figure 5. Regarding the color of colonies of isolates on PDA, F. solani Fs 1 and F. sambucinum Fs 3 (left); F. sambucinum Fs2 and F. sambucinum Fs4 (right)

All inoculated tubers indicated dry rot symptoms with different degrees against $F$. sambucinum (Fs2, Fs3 and Fs4). Fs2 and Fs4 isolates shared similar levels of pathogenicity, whereas Fs3 caused more severe diseases (Fig. 6). Maybe we can make hypothesis that the dark pink of $F$. sambucinum isolates that developed on the medium had more virulence on the potato. Aydin et al. (2016) studied with a dark pink of $F$. 
sambucinum isolate on potato and assumed that the sprouts of tubers were infected with systemic symptoms and severely rot. Thus, it has been suggested that this isolate may be different from other in terms of both the symptom and the severity of the disease.

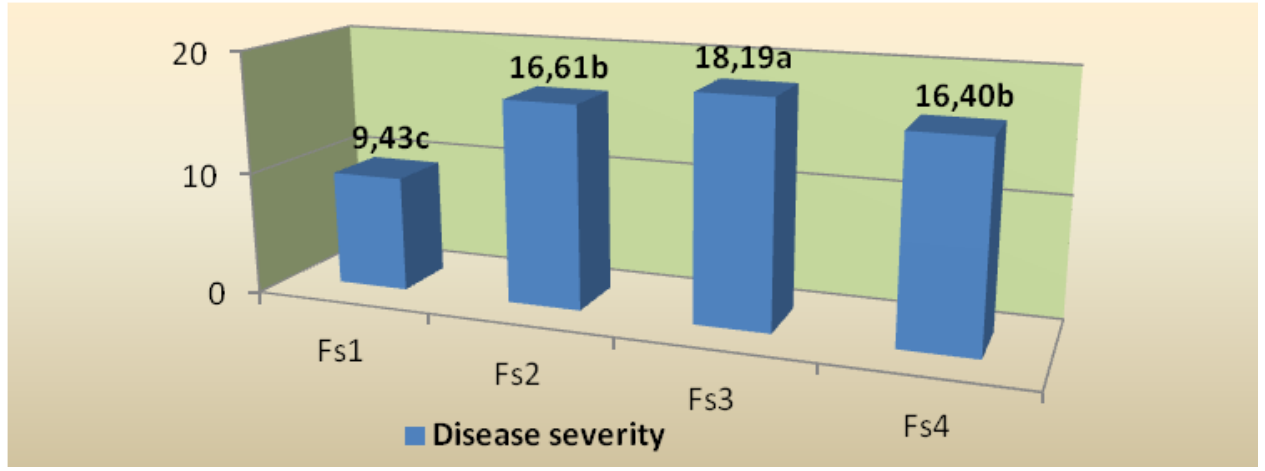

Figure 6. The mean severity of dry rot caused by $F$. solani (Fs1) and F. sambucinum (Fs2, Fs3 and $F s 4)$ isolates on potato

This result shows that the isolates of $F$. sambucinum may be different from each other in terms of virulence. As already noted other researchers have also reported that the majority of the $F$. sambucinum isolates were pathogenic to the potato and caused an average lesion of $21.6 \mathrm{~mm}$. But only one $F$. sambucinum isolate caused an average lesion size that was considerably lower, at $12.1 \mathrm{~mm}$ (Stefańczyk et al., 2016).

\section{Conclusion}

Briefly, dry rot disease caused by $F$. sambucinum is an economically important field and a postharvest disease throughout the world. This study also reached the conclusion that some strain of $F$. sambucinum investigated were aggressive than the others and caused more severe tuber rots compared to $F$. solani. Many potato cultivars used in this study were susceptible hosts to the pathogen $F$. sambucinum. Only one cultivar showed less or moderate susceptible to pathogen. Phylogenetic tree generated from the ITS sequence data is found to have a quite consistent resolution with our estimations.

\section{REFERENCES}

[1] Abd-Elsalam, K. A., Aly, I. N., Abdel-Satar, M. A., Khalil, M. S., Verreet, J. A. (2003): PCR identification of Fusarium genus based on nuclear ribosomal-DNA sequence data. African Journal of Biotechnology 2(4): 96-103.

[2] Al-Mughrabi, K. I. (2010): Biological control of Fusarium dry rot and other potato diseases using Pseudomonas fluorescens and Enterobacter cloacae. - Biological Control 53: 280-284.

[3] Aydin, M. H., Pala, F., Kaplan, C. (2016): Potato tuber sprout rot caused by Fusarium sambucinum in Turkey. - Scientific Papers. Series A. Agronomy 59: 189-193.

[4] Baturo-Cieśniewska, A., Lenc, L., Grabowski, A., Łukanowski, A. (2015): Characteristics of Polish isolates of Fusarium sambucinum: molecular identification, pathogenicity, diversity and reaction to control agents. - American Journal of Potato Research 92: 49-61.

[5] Boyd, A. E. W. (1972): Potato storage diseases. - Review Plant Pathology 51: 297-321. 
[6] Booth, C. (1977); Fusarium: laboratory guide to the identification of the major species. Common Wealth Mycological Institute, Kew, Surrey, UK.

[7] Borca, I. D., Carmen, E. P. (2013): Studies regarding the morphological identification of Fusarium sambucinum Fuckel isolated from potato tubers. - ProEnvironment 6: 59-63.

[8] Burgess, L. W., Summerell, B. A., Bullock, S., Gott, K. P., Backhouse, D. (1994): Laboratory Manual for Fusarium Research. 3rd ed. - University of Sydney and Botanic Garden, Sydney, Australia.

[9] Burkhart, C. R., Chirist, B. J., Haynes, K. G. (2007): Non-additive genetic variance governs resistance to Fusarium dry rot in a diploid hybrid potato population. - American Journal of Potato Research 84: 199-204.

[10] Choiseul, J., Allen, L., Carnegie, S. (2007): Fungi causing dry tuber rots of seed potatoes in storage in Scotland. - Potato Research 49: 241-253.

[11] Corsini, D. L., Pavek, J. J. (1986): Fusarium dry-rot resistant potato germplasm. American Potato Journal 63: 629-638.

[12] Cullen, D. W., Toth, I. K., Pitkin, Y., Boonham, N., Walsh, K., Barker, I., Lees, A. K. (2005): Use of quantitative molecular diagnostic assays to investigate Fusarium dry rot in potato stocks and soil. - Phytopathology 95: 1462-1471.

[13] Daami-Remadi, M., Ayed, F., Jabnoun-Khiareddine, H., Hibar, K., El Mahjoub, M. (2006): Comparative susceptibility of some local potato cultivars to four Fusarium species causing tuber dry rot in Tunisia. - Journal of Plant Sciences 1(4): 306-314.

[14] Daami-Remadi, M.., Khiareddine, H. J., Ayed, F., Mahjoub, M. E. (2016): Effect of Temperature on aggressivity of Tunisian Fusarium species causing potato (Solanum tuberosum L.) tuber dry rot. - Journal of Agronomy 5(2): 350-355.

[15] Doyle, J. J. (1987): A rapid DNA isolation procedure for small quantities of fresh leaf tissue. - Phytochemical Bulletin 19: 11-15.

[16] Du, M., Ren, X., Sun, Q., Wang, Y., Zhang, R. (2012): Characterization of Fusarium spp. causing potato dry rot in China and susceptibility evaluation of Chinese potato germplasm to the pathogen. - Potato Research 55: 175-184.

[17] Duggal, A., Dumas, M. T., Jeng, R. S., Hubbes, M. (1997): Ribosomal variation in six species of Fusarium. - Mycopathology 140: 35-49.

[18] Eken, C., Demirci, E., Sahin, F. (2000): Pathogenicity of the fungi determined on tubers from potato storages in Erzurum, Turkey. - Journal of Turkish Phytopathology 29: 61-69.

[19] Estrada, J. R., Gudmestad, N. C., Rivera, V. V., Secor, G. A. (2010): Fusarium graminearum as a dry rot pathogen of potato in the USA: prevalence, comparison of host isolate aggressiveness and factors affecting etiology. - Plant Pathology 59: 1114-1120.

[20] Gachango, E., Hanson, L. E., Rojas, A., Hao, J. J., Kirk, W. W. (2012): Fusarium spp. causing dry rot of seed potato tubers in Michigan and their sensitivity to fungicides. Plant Disease 96: 1767-1774.

[21] Gerlach, W., Nirenberg, H. (1982): The genus Fusarium-A pictorial atlas. - Mitteilungen aus der Biologischen Bundesanstalt Für Land- und Forstwirtschaft (Berlin - Dahlem) 209: 1-405.

[22] Hanson, L. E., Schwager, S. J., Loria, R. (1996): Sensitivity to thiabendazole in Fusarium species associated with dry rot of potato. - Phytopathology 86: 378-384.

[23] Hasenekoğlu, I. (1991): Toprak Mikrofungusları, Cilt 1-VII. - Kazım Karabekir Eğitim Fakultesi Basımevi, Erzurum.

[24] Hide, G. A., Read, P. J., Hall, S. M. (1992): Resistance to thiabendazole in Fusarium species isolated from potato tubers affected by dry rot. - Plant Pathology 41: 745-748.

[25] Hooker, W. J. (1981): Compendium of Potato Diseases. - American Phytopathological Society, St. Paul, MN.

[26] Huaman, Z., Tivoli, B., de Lindo, L. (1989): Screening for resistance to Fusarium dry rot in progenies of cultivars of $S$. tuberosum ssp. and/gena with resistance to Erwinia chrysanthemi. - American Potato Journal 66: 357-364. 
[27] Jellis, G. J. (1975): Screening potato clones for resistance to dry rot (Fusarium solani var. coeruleurn). - Annals of Applied Biology 81: 417-418.

[28] Jellis, G. J., Starling, N. C. (1983): Resistance to powdery dry rot (Fusarium sulphureum) in potato tubers. - Potato Research 26: 295-301.

[29] Kumar, G. N., Knowles, N. R. (2003): Wound-induced superoxide production and PAL activity decline with potato tuber age and wound healing ability. - Physiologia Plantarum 117: 108-117.

[30] Lapwood, D. H., Read, P. J., Spokes, J. (1984): Methods for assessing the susceptibility of potato tubers of different cultivars to rotting by Erwinia carotovora subsp. atroseptica and carotovora. - Plant Pathology 33: 13-20.

[31] Latus-Zietkiewicz, D., Perkowski, J., Chelkowski, J. (1987): Fusarium species as pathogens of potato tubers during storage and their ability to produce mycotoxins. Mycotoxin Research 1: 99-104.

[32] Leach, S. S., Nielsen, L. W. (1975): Elimination of fusarial contamination on seed potatoes. - American Potato Journal 52: 211-218.

[33] Lenc, L., Lukanowski, A., Sadowski, C. Z. (2008): The use of PCR amplification in determining the toxigenic potential of Fusarium sambucinum and F. solani isolated from potato tubers with symptoms of dry rot. - Phytopathologia Polonica 48: 13-23.

[34] Leslie, J. F., Summerell, B. A. (2006): The Fusarium Laboratory Manual. 1st ed. Blackwell Publishing Ltd. Oxford, London.

[35] Lynch, D. R., Kawchuk, L. M., Chen, Q., Kokko, M. (2003): Resistance to Fusarium sambucinum in wild and cultivated Solanum species. - American Journal of Potato Research 80: 353-358.

[36] Mishra, P. K., Fox, R. T. V., Culham, A. (2003): Development of a PCR-based assay for rapid and reliable identfication of pathogenic Fusaria. - FEMS Microbiology Letters 218: 329-332.

[37] Nelson, P. E., Toussoun, T. A., Cook, R. J. (1981): Fusarium: diseases, biology and taxonomy. - The Pennsylvania State University Press, University Park, Pennsylvania, USA.

[38] Nelson, P. E., Toussoun, T. A., Marasas, W. F. O. (1983): Fusarium Species: An Illustrated Manual for Identification. - Pennsylvania State University Press, University Park, Pennsylvania, USA.

[39] O’Donnell, K. (1992): Ribosomal DNA internal transcribed spacers are highly divergent in the phyto pathogenic ascomycete Fusarium sambucinum (Gibberella pulicaris). Current Genetics 22: 213-320.

[40] Oechsler, R. A., Feilmeier, M. R., Ledee, D. R., Miller, D., Diaz, M. R., Fini, M. E., Fell, J. W., Alfonso, E. C. (2009): Utility of molecular sequence analysis of the ITS rRNA region for identification of Fusarium spp. from ocular sources. - Investigative Ophthalmology \& Visual Science 50: 2230-2236.

[41] Peters, J. C., Lees, A. K., Cullen, D. W., Sullivan, L., Stroud, G. P., Cunnington, A. C. (2008): Characterization of Fusarium spp. responsible for causing dry rot of potato in Great Britain. - Plant Pathology 57: 262-271.

[42] Powell, W., Morgante, M., Andre, C., Hanafey, M., Vogel, J., Tingey, S., Rafalski, A. (1996): The comparison of RFLP, RAPD, AFLP and SSR (microsatellite) markers for germplasm analysis. - Molecular Breeding 2: 225-238.

[43] Richardson, K. E., Hamilton, P. B. (1987): Preparation of 4,15-Diacetoxyscirpenol from Cultures of Fusarium sambucinum NRRL 13495. - Applied and Environmental Microbiology 53(2): 460-462.

[44] Schisler, D. A., Slininger, P. J., Bothast, R. J. (1997): Effects of antagonists cell concentration and two-strain mixtures on biological control of Fusarium dry rot of potatoes. - Phytopathology 87: 177-183. 
[45] Secor, G. A., Sales, B. (2001): Fusarium Dry Rot and Fusarium wilt. - In: Stevenson, W. R. et al., (eds.) Compendium of Potato Diseases. 2nd ed. - The American Phytopathological Society, St. Paul, MN, pp. 23-25.

[46] Senter, L. H., Sanson, D. R., Corley, D. G., Tempesta, M. S., Rottinghaus, A. A., Rottinghaus, G. E. (1991): Cytotoxicity of trichothecene mycotoxins isolated from Fusarium sporotrichioides (MC-72083) and Fusarium sambucinum in baby hamster kidney (BHK-21) cells. - Mycopathology 113: 127-131.

[47] Stefańczyk, E., Sobkowiak, S., Brylińska, M., Śliwka, J. (2016): Diversity of Fusarium spp. associated with dry rot of potato tubers in Poland. - European Journal of Plant Pathology 145: 871-884.

[48] Sveeney, M. J., Dobson, A. D. W. (1999): Molecular biology of mycotoxins biosynthesis - FEMS Microbiology Letter 175: 149-163.

[49] Tamura, K., Dudley, J., Nei, M., Kumar, S. (2007) MEGA4: molecular evolutionary genetics analysis (MEGA) software version 4.0. Molecular biology and evolution 24 (8):1596-1599.

[50] Tivoli, B., Abdul Razzaq, K., Jouan, B., Lemarchand, E. (1986): Comparative study of the infective potential of different species or varieties of Fusarium, causal agents of dry rot in potato tubers. - Potato Research 29: 12-32.

[51] Turner, A. S., Lees, A. K., Rezanoor, H. N., Nicholson, P. (1998): Refinement of PCRdetection of Fusarium avenaceum and evidence from DNA marker studies for phenetic relatedness to Fusarium tricinctum. - Plant Pathology 47: 278-288.

[52] Valluru, R., Christ, B. J., Haynes, K. G., Vinyard, B. T. (2006): Inheritance and stability of resistance to Fusarium tuber rot in tetraploid potatoes. - American Journal of Potato Research 83(4): 335-341.

[53] Vance, C. P., Kirk, T. K., Sherwood, R. T. (1980): Lignification as a mechanism of disease resistance. - Annual Review of Phytopathology 18: 259-288.

[54] Visentin, I., Tamietti, G., Valentino, D., Portis, E., Karlovsky, P., Moretti, A., Cardinale, F. (2009): The ITS region as a taxonomic discriminator between Fusarium verticillioides and Fusarium proliferatum. - Mycological Research 113: 1137-1145.

[55] Wang, H., Xiao, M., Kong, F., Chen, S., Dou, H. T., Sorrell, T., Li, R. Y., Xu, Y. C. (2011): Accurate and practical identification of 20 Fusarium species by seven-locus sequence analysis and reverse 72 line blot hybridization, and an in vitro antifungal susceptibility study. - Journal of Clinical Microbiology 49: 1890-1898.

[56] Wastie, R. L., Jellis, G. J., Lapwod, D. H., Logan, C., Little, G., Phillips, M. S. (1988): Assessing potato cultivars for resistance to tuber soft rot (Erwinia carotovora subsp. atroseptica) at four test centers in the UK. - Potato Research 31: 67-72.

[57] Wastie, R. L., Stewart, H. E., Brown, J. (1989): Comparative susceptibility of some potato cultivars to dry rot caused by Fusarium sulphurum and Fusarium solani var. coeruleum. - Potato Research 32: 49-55.

[58] White, T. J., Bruns, T., Lee, S., Taylor, J. W. (1990): Amplification and Direct Sequencing of Fungal Ribosomal RNA Genes for Phylogenetics. - In: Innis, M. A., Gelfand, D. H., Sninsky, J. J., White, T. J. (eds.) PCR Protocols: A Guide to Methods and Applications. - Academic Press, Inc., New York, pp. 315-322. 